\title{
FACTORS AFFECT BUDGET ABSORPTION IN GOVERNMENT INSTITUTIONS OF INDONESIA, 2017
}

\author{
Reny Andriati ${ }^{1}$ \\ ${ }^{1}$ Magister of Applied Economics, Faculty of Economics and Business, Padjadjaran University \\ 11andriarey@gmail.com
}

DOI: https://doi.org/10.18196/jgpp.62110

Article Info

Article history

Received 29 Apr 2019

Revised 07 May 2019

Accepted 20 May 2019

Keywords : budget absorption, government institution, multinomial linier regression

\section{ABSTRACT}

The purpose of this research is to analyse and examine the effect of total budget, opinion of financial performance, corruption perception index, and performance accountability on the budget absorption in the Government Institutions. It is an associative-causal research. This research includes 66 government institutions which have complete dataset for research variables. The data were the secondary data in the form of financial publications of the government institutions in Indonesia. The hypotheses were tested with the multinomial linear regression analysis. The results of this research showed that, simultaneously, total budget, opinion of performance, corruption perception index, and performance accountability affected the budget absorption in government institutions. After the research was conducted and it was analysed statistically, only one variable were highly significant to the accumulation of budget absorption that is opinion of performance of a government institution.

\section{INTRODUCTION}

A budget is an essential tool that guides decision making and coordinates the activities of divisions within an organization. The process of budgeting engages the heads of divisions to provide input on the needs of their units based on their planned activities. The budget guides resource allocation across departments for them to realize their objectives for the year. Budget also forms a basis of setting goals and can actually be monitored and used to measure the performance of an institution. Starting from the definition of budget, the follow-up of budget is to realize the budget that has been allocated in accordance with what has been determined in the institutional budget. In this case, the follow up is the realization of the activities that have been planned to be implemented within one fiscal year. Thus, the achievement of the realization of activities that have been planned is a reflection of budget absorption.

The government of Indonesia has long experienced an uneven pattern of budget realization. Institution in Indonesia showed small absorption in the first three-quarters and then piled up in the last quarter. An increase in spending at the end of year 
eventually led to inadequate quality of work on the national economy. One of hindrances of economic growth is slow budget absorption. Absorption delay in government institution budget also hampers community's activities.

Governmental spending significantly affects economic growth. Capital and goods spending secures a strategic position in improving the speed of national economic growth. Government's institution expenditure may play a role as the prime mover in government institution. If budget cannot be absorbed ideally, government's performance is rated poor. Cooperation strategy with government is assisted by Ministry of Finance, to ensure that all programs' budget can be absorbed well. This initiative may quickly bring impact in promoting economic growth and improving government's performance. Economic growth occurs if approved programs implemented in the right time.

A pragmatically step to catch up budget realization deadline was by accelerating budget realization in order to obtain the target in the end of fiscal year. As a result, there was an accumulation of expenditures at the end of the year which eventually led to second-class quality of work and the generated impact on the national economy which is no longer optimal.

Figure 1. Percentage of Budget Absorption in Government Institution of Indonesia (20102017)

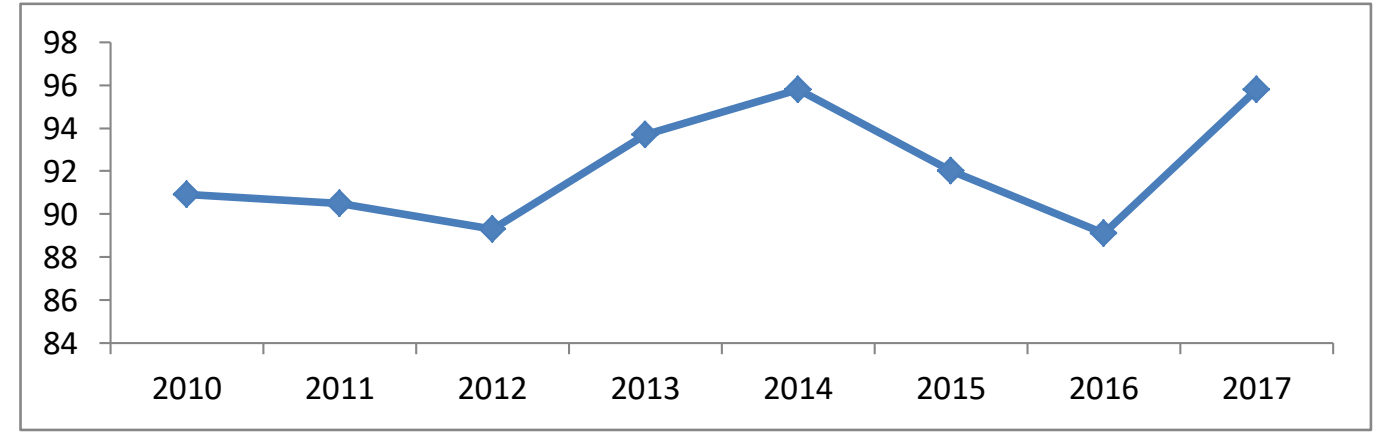

Source: Ministry of Finance

The condition above reflects that there is a problem in the process of expenditure budget absorption. It turns out in general that the conditions of the government institutions expenditure absorption from 2010 to 2017 are low. Low realization of the government institution's expenditure is caused by, one of them, that in the first quarter all new tender processes has just started and it takes at least 2 
months starting from the announcement of the bidding until the determination of the winning bidder. Therefore, in the second quarter and even in the third quarter the activity implementation starts.

Some things which are very likely to be the cause of such delays include the delays in the establishment of institutional government budget, unfinished bidding process or also other technical problems which resulted in the realization of capital expenditure after the revision in the institutional government budget (mostly conducted in August-September). And in the fourth quarter, the realization of capital expenditure rises significantly, but it does not reach $100 \%$ of the main budget. This is due to the same problems as the previous quarters, such as the determination of the government institution budget, the revision of government institution is overdue, the efficiency of capital expenditures and various efficiency policies.

Budgetary absorption capacity represents the efficiency and effectiveness to which an institution is capable of spending allocation of its structural funds, that is expressed in percentage form of the entire allocations. Absorption is related by experts in three main characteristics namely financial capacity which is the ability to cofinance activities and projects supported by the government, macroeconomic capacity as well as the capacity in its administration which is how well the local and central authorities are able to oversee the government projects and activities. (Hassan, 2013). Several studies have been conducted to determine the problem of delay budget realization in government institution. There are various factors that cause low budget absorption in the fiscal year as follows:

First, total budget which is not well-prepared will also have the impact on the evaluation and revision continuously by the relevant officials on the planning aspect. If it lasts longer, the implementation of the budget for development program will be retarded and delay the schedule. In the end, the budget cannot be used and ultimately congested. (Georgescu \& Zaman, 2009)

Second, opinion of financial performance based on relevant authorities reflects administration system and accounting procedures in budget implementation. The administration of government institution financial and the policy of government 
104 institution budget management is not clearly structured. The preparations of financial reports and expenditures are not supported by relating documents. Government Institution financial statement which is the responsibility report of the use of the budget cannot be accounted maximally by the relevant authorities. If these things happen within a long time, budget will be congested. (Erlina, Saputra, A., \& Muda, I., 2017)

Third, Corruption Perception Index (CPI) published annually by StatisticsIndonesia on behalf for Ministry of Reform and Bureaucracy which ranks institutions by their perceived levels of public sector corruption, as determined by expert assessments and opinion surveys. The delivery of effective public service requires well developed inputs of minds that are determined by perception of civil servants in a government agency or department. (Thomas, 2018)

Forth, performance accountability is triggered by the release of funds to the different agencies for spending. Any occasioned delays in disbursement of funds to the institutions significantly results in delayed implementation of projects and leaves an organization with unspent funds. In the public sector the ministries, state departments and agencies have a role in determining the release of funds. The Ministry of Finance for instance releases budgeted funds based on submission of satisfactory work plans and progress reports by the spending agencies. Any delays in submission of the required reports subsequently causes delay in release of finances. (Fitriani, Masdjodjo, \& Suwarti, 2015)

\section{Figure 2. Reseach Framework}

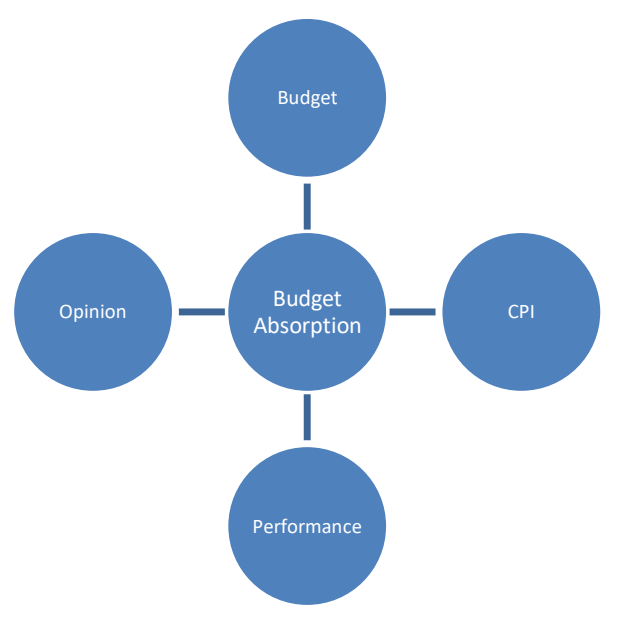




\section{RESEARCH METHOD}

A sampling frame in this research is a list of the government institutions of Indonesia. The study purposively sought information from report of government institutions under coordination from ministry of finance. Owing to the fact that not all the government institutions completed the data for research variables, the sampling frame was 66 government institutions within the ministry of finance of Indonesia

The data used in this study were the cross-sectional data in 2017. Cross-sectional data is the data collected at a point of time. In this research, the researcher used secondary data obtained from the Ministry of Finance (2017) and Statistics Indonesia (2017).

\section{Multinomial Linier Regression}

Most of the researches in budget absorption used Multinomial Linier Regression using Ordinary Least Square Method to perform their models. These models were made to detect variables which significantly affect budget absorption in government institution of Indonesia.

Diagnostic Tests

Diagnostic tests check on multivariate data analysis procedures are a set of expectations that are based on the theory of statistics. It is important to check that the assumptions of multiple linear regressions are fulfilled to ensure that the coefficients are Best Linier Unbiased Estimators (BLUE). (Gujarati, 2004)

\section{Multicollinearity Test}

Multiple regression assumes that the independent variables are not highly correlated with each other. This assumption is tested using Variance Inflation Factor (VIF) values. The VIFs of the linear regression indicate the degree that the variances in the regression estimates are increased due to multicollinearity. VIF values higher than 10 indicate that multicollinearity is a problem. From the result, it can be concluded that all variables have VIF value of 1 and less than 2, as a result no multicollinearity assumption is fulfilled. 
Table 1. Collinearity Diagnostic Test between Variables

\begin{tabular}{lll}
\hline Variables & \multicolumn{2}{c}{ Collinearity Statistics } \\
\cline { 2 - 3 } & Tolerance & VIF \\
\hline Budget in billion rupiahs & .946 & 1.057 \\
Opinion of Performance & .912 & 1.097 \\
Corruption Perceptions & .966 & 1.035 \\
Index & .906 & 1.104 \\
Performance & & \\
Accountability of & & \\
Government Institutions & \\
\multicolumn{2}{c}{ Source: SPSS calculation }
\end{tabular}

Heteroscedasticity

This assumption states that the variance of error terms is similar across the values of the independent variables. Figure 2 depicted a plot of standardized residuals versus predicted values. The figure shows points are equally distributed across all values of the independent variables (budget absorption).

Figure 3. Heteroscedasticity Scatter Plot Test

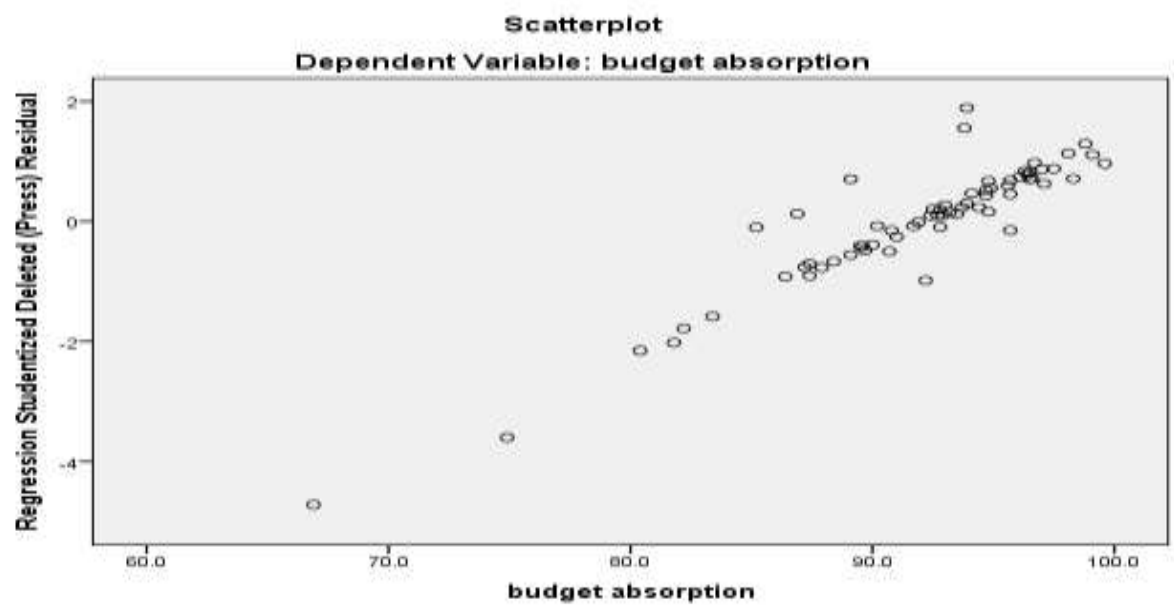

Source: SPSS tabulation

Autocorrelation Test

No autocorrelation between disturbances is important assumption of multiple linier regression model. This autocorrelation can be detected with Durbin-Watson value. The DW-stat 1.253 is in no auto correlation region, so there is no autocorrelation between disturbances.

Table 2. Autocorrelation Test between Variables

\begin{tabular}{lcrr}
\hline Model & $\mathrm{R}$ & $\mathrm{R}$ Square & Durbin-Watson \\
\hline 1 & $.373^{\mathrm{a}}$ & .139 & 1.931 \\
\hline \multicolumn{3}{c}{ Source: SPSS calculation }
\end{tabular}




\section{Hypothesis Testing}

The hypothesis the researchers used in this research are as follows:

$\mathrm{H}_{0}$ : The independent variables including budget planning, budget implementation, internal of work units, human resources, documents, and administration partially do not have effect on the accumulation of budget absorption. $\mathrm{H}_{1}$ : The independent variables including budget planning, budget implementation, internal of work units, human resources, documents, and administration have significant effect on the accumulation of budget absorption.

F Test

$F$ test (ANOVA) is used to test the effect of independent variables on dependent variables simultaneously with the criteria of the significance level of 0.1 and F-count is greater than F-table. When the significance probability is smaller than 0.1 , it means that independent variables jointly have significant effect on dependent variables. Then, if the significance probability is greater than 0.1 , it means that independent variables jointly do not have significant effect on dependent variables.

Table 3. Analysis of Variance Test

\begin{tabular}{lrrrrr}
\hline Model & Sum of Squares & df & Mean Square & F & Sig. \\
\hline Regression & 298.824 & 4 & 74.706 & 2.465 & $.054^{\mathrm{b}}$ \\
\hline Residual & 1848.765 & 61 & 30.308 & & \\
\hline Total & 2147.590 & 65 & & & \\
\hline
\end{tabular}

Source: SPSS calculation

From these results, the variables total budget, opinion of performance, corruption perception index, and performance accountability are jointly significant to the budget absorption in government institutions since the F-statistics has a probability value $(0.54)$ that is less than alpha (0.1). This suggests the budget absorption model that has the variables total budget, opinion of performance, corruption perception index, and performance accountability.

\section{RESULT AND DISCUSSION}

After the research was conducted and it was analysed statistically, the partial test of independent variables shows that only one variable was highly significant to the accumulation of budget absorption that is opinion of budgeting performance. The probability value of this variable is below alpha $5 \%$. The other variables are not significant. 
Table 4. Estimation of Multiple Linier Regression Model

\begin{tabular}{lcrrr}
\hline Model & Unstandardized Coefficients & \multicolumn{2}{l}{ Sig } \\
\cline { 2 - 4 } & $\mathrm{B}$ & \multicolumn{2}{l}{ Std. Error } & \\
\hline (Constant) & 74.904 & 21.413 & .001 \\
\hline in billion rupiahs & 0.000045 & .000 & .202 \\
\hline Opinion & 5.861 & .469 & .021 \\
\hline $\begin{array}{l}\text { Corruption } \\
\text { Perceptions Index }\end{array}$ & .107 & .839 & .654 \\
\hline $\begin{array}{l}\text { Performance } \\
\text { Accountability }\end{array}$ & .510 & .568 \\
\hline $\begin{array}{c}\text { Source: SPSS calculation } \\
\text { BudgetAbsorption }\end{array}$ & $=74.904-5.861$ opinion & &
\end{tabular}

The model illustrates that the increase of one levels of BPS opinions on financial administrations, will increase 5 to 6 percentage budget absorption in an institution.

This research on government institutions in Indonesia in 2017 has two conclusions. First, BPK opinions on financial administration reports have an impact on budgetary absorption. Releasing fund late is the reason for not implementing or delaying ongoing projects and planned activities which mostly require continuous and cash flow that is predictable. Responsibility of financial administration has a great effect on budgetary absorption. Public finance field suggests that more emphasis must be given to institutional changes for example reforms in revenue administration. This is in addition to management style, administrative structure, organizational culture and staff retraining should be given equally priority to technical processes and system reforms.

Second, total budget, corruption perception index, and performance accountability fiscal accountability reviews have less impact on budgetary absorption in this research.

\section{CONCLUSION}

Based on the research findings, financial administration should be engaged in the budget implementation. Government Institutions should undertake effective financial control processes to ensure that funds are utilized optimally and for the intended purposes. This in turn leads to improved financial performance.

Government Institutions should manage their budgets to eradicate extravagance and use funds for stipulated purposes. Government Institutions should undertake 
regular financial audits in order to identify discrepancies in the expenditures. This may help in identifying the relevant controls that may be put in place to boost financial performance.

Government Institutions should adopt fiscal accountability measures which may include segregation of accounting activities eventually leading to improved performance. Financial experts need to develop a budget theoretical formulation that can be applied to each area so that the decision makers and budget implementers can make this theory as an ideal foothold in the realization of budget implementation.

\section{REFERENCES}

Erlina, Saputra, A., \& Muda, I. (2017). The Analysis of The Influencing Factors of Budget Absorption in North Sumatera. International Journal of Economic Research, 287-300.

Fitriani, N., Masdjodjo, G. N., \& Suwarti, T. (2015). Exploring The Factors that Impact The Accumulation of Budget Absorption in The End of Fiscal Year 2013: A Case Study in Pekalongan City of Central Java Indonesia. South East Asia Journal of Contemporary Business, Economics, and Law, 50-57.

Georgescu, G., \& Zaman, G. (2009). Structural Fund Absorption: A New Challenge for Romania. Romanian Journal of Economic Forecasting, 136-154.

Gujarati, D. N. (2004). Basic Econometrics. New York: The McGraw-Hill Companies.

Hassan, S. M. (2013). Public Financial Management Practices Effect on Budgetary Absorption in Madera County Kenya. Kenyatta University.

Keuangan, B. P. (2017). Laporan Hasil Pemeriksaan atas Laporan Keuangan Pemerintah Pusat. Jakarta: Badan Pemeriksa Keuangan.

Statistik, B. P. (2017). Survei Hasil Pelaksanaan Reformasi Birokrasi. Jakarta: Badan Pusat Statistik.

Thomas, N. I. (2018). Factors Influencing Absorption of Budgeted Funds in The Kenyan Public Sector. KCA University. 